Article

\title{
Evaluation of Sustainability Practices in Small and Medium-Sized Manufacturing Enterprises in Southern Brazil
}

\author{
Fabricio Carlos Schmidt ${ }^{1, *}$, Roselaine Ruviaro Zanini ${ }^{2}$, André Luis Korzenowski ${ }^{1,3}$, \\ Reno Schmidt Junior ${ }^{1}$ (D) and Karl Benchimol Xavier do Nascimento 4 (i) \\ 1 Polytechnic School, University of Vale do Rio dos Sinos (UNISINOS), Av Unisinos, 950, \\ São Leopoldo/RS 93020-190, Brazil; akorzenowski@unisinos.br (A.L.K.); schmidt.reno@gmail.com (R.S.J.) \\ 2 Immaculate Conception School (UFSM), Andradas Street, 1614. Downtown, \\ Santa Maria/RS 97105-900, Brazil; rrzanini@smail.ufsm.br \\ 3 Business School, University of Vale do Rio dos Sinos (UNISINOS), Av Dr. Nilo Peçanha, 1600, \\ Porto Alegre/RS 91.330-002, Brazil \\ 4 Regional University of the Northwest of the State of Rio Grande do Sul (UNIJUI), Prefeito Rudi Franke \\ Avenue, s/n, Arco Iris, Panambi/ RS 98280-000, Brazil; karl@amazonind.com.br \\ * Correspondence: fabricioschmidt@gmail.com; Tel.: +55-55-99929-9633
}

Received: 24 May 2018; Accepted: 10 July 2018; Published: 13 July 2018

\begin{abstract}
The purpose of this article is to analyze the performance of small and medium-sized enterprises (SMEs) manufacturing, aiming to identify the main practices of sustainability, including the values and transparency, internal audience, environment, supplier relationships, customer and/or consumer relationships, and community relationships. In order to develop this research, a questionnaire was applied on the subject in question, through which the companies were classified as to their reality in relation to corporate social responsibility. Based on the analysis, it was observed that five of these companies obtained a score that indicates that the companies have already assimilated the associated concepts and are clear of the necessary commitments for a socially responsible action. However, given the results obtained, it is possible to conclude that there is a need to strengthen the actions to be taken with regard to corporate social responsibility, since no company has positioned itself in excellence. In addition, some suggestions for new research were identified and discussed in the analysis of the results.
\end{abstract}

Keywords: sustainability; SMEs; competitiveness; environmental management

\section{Introduction}

Since the first discussions in 1950 to the present, there has been no consensus on the sustainability concept. Actually, there are no definitions or content boundaries to scholars in this field [1,2]. It is visible that civil and economic society has adapted to the concept that companies should act in social areas (previously only addressed by the State), extending their actions to the whole society and not only to its own employees and shareholders [3-5]. Sustainability is associated with the recognition that the decisions and results of the activities of companies reach a universe of social actors, broader than the one composed by its partners and shareholders [6-8].

In Brazil, sustainability became strategic since the 1990s, due to the demand for an increase in the performance indicators of Brazilian companies. These companies needed to achieve new markets or receive investments of global capital markets, among others. As an outcome, these companies started to be charged with having to assume their share of responsibility within society $[9,10]$. Sustainability initiatives, which recommend a synergy between operational results, respect for people, 
and preservation of the environment are also valued items by customers and should therefore be considered by companies in their production systems [11].

Due to market competition and globalization, companies are crossing a wide range of changes in their business environment, adopting more ethical procedures of corporate social action to achieve long-term goals, rather than focusing on the short-term perspective of profit creation $[6,12]$.

According to $[6,13]$, the basic purpose of business is to provide profit and figure out ways to maximize earnings. In addition, the authors report that ventures are required to bear some indirect costs that are not directly related to profitability, and which are pressured to commit to in order to survive in a competitive market, one of which is Corporate Social Responsibility (CSR).

As said by [14], a CSR presents a win-win scenario, allowing companies to simultaneously increase their profitability and produce social benefits [15]. CSR practices the fostering of relationships of trust between stakeholders, and in addition, sustainability-based business models help companies to create an environment of trust for innovation, which leads to the development of long-term competitiveness [16].

In spite of the positive arguments to adopt social responsibility practices, there are some who are against social responsibility. On the other hand, there are certification standards such as the International Organization for Standardization (ISO) 26000, in which the CSR refers to good corporate governance, operating ethically and sustainability, and carrying out a set of voluntary commitments to manage its impact in the social, environmental, and economic fields, obtaining the maximum benefits for the whole society $[17,18]$.

The literature on sustainable business practices has focused on large companies, such as multinationals, whose individual impacts are significant $[19,20]$. However, although SMEs have relatively little individual importance, associatively they can have great impacts on the regions where they are operating, playing a very important and crucial role in the world economy. This characteristic is relevant in certain regions or countries, such as Latin America, where $95 \%$ of its fabric business are SMEs. So, it is very important to take into account the strategic role of these types of companies in the economy, and the economic, social, and environmental impact of their activities taken together [21,22]. The integration of social responsibility by SMEs can be achieved through practical, simple, and cost-effective actions, and do not need to be complex or expensive. Due to the small size and the potential of being more flexible and innovative, SMEs can, in fact, bring novelties to good social responsibility opportunities $[23,24]$.

This paper focuses on the sustainability theme as this theme raises different criticisms or points of view $[25,26]$, due to its wide content, and can be interpreted as a new model of development or just a redesign of capitalism $[13,24,27,28]$. Increasingly, many companies are implementing sustainability-oriented strategies; for example, it was observed that Embraer has integrated the CSR practices with other existing management systems in a harmonious and mature form [9], and in the same way, several researchers $[2,13,22,25,29,30]$ dedicate themselves to studying this theme.

However, different opinions and approaches on how to deal with issues related to sustainability are perceived in this process. The objective of this research is to analyze the main sustainability practices of small and medium-sized manufacturing enterprises. The analysis covered the values and transparency, internal audience, environment, supplier relationships, customer and/or/consumer relationships, and community relationships.

The questionnaire was designed using the indicators of the Ethos Institute as a reference, which is a Brazilian nongovernmental organization founded in 1998, with the aim to mobilize, sensitize, and support companies in the incorporation of sustainability and corporate social responsibility in their business strategies. This management tool is free of charge and can be used by all companies, regardless of their size and sector of activity. In view of our investigation, the questionnaire was structured into two different parts: general data of the company that enables us to define the profile, and the sustainability indicators that are to be measured. 
These indicators introduce a new approach to the management of companies, integrating CSR principles and behavior based on the concept of sustainable and responsible business. Their purpose is to evaluate how much sustainability and social responsibility has been incorporated into businesses. The Ethos Institute groups them into the areas of human rights, labor standards, environmental protection, and the fight against corruption [21].

The relevance of the study is centered on the fact that it allows us to provide relevant information to managers on their level of sustainability implementation, showing their weaknesses and strengths in terms of sustainability. In addition, this research proposes several alternatives for SMEs to improve their sustainable performances. Furthermore, a tool for measuring sustainability is validated, with the aim of providing a tool for Brazilian companies to know the degree of maturity in the sustainable management of their business fabric and to monitor the progress made in this area.

Our results show that there are significant differences in environmental commitment in favor of companies with higher revenues. Although this is not the rule, the sustainable practices of companies with lower billings have also attracted attention, but in isolation. A positive point is that all companies are aware of the importance of sustainability and that this is a path without a return which will stand out in the market, based on which companies will be able to act proactively in search of the best practices of sustainability. The paper is organized as follows: after the introduction, which has also brought up updated references on the subject, Section 2 presents the Materials and Methods for this research and Section 3 shows the results, followed by the discussion. At the end, final remarks and a research agenda are presented.

\section{Materials and Methods}

Case study has been one of the most powerful research methods in operations management, particularly in the development of a new theory. The results may have high academic impact, unrestricted by the strict limits of the models, and may lead to new and creative perspectives [31]. This study was applied to sixteen small and medium-sized manufacturing enterprises from the metal-mechanic sector located in Rio Grande do Sul, south of Brazil. The criteria used to classify companies' size are an important factor in supporting SMEs, allowing establishments within the established limits to enjoy the benefits and incentives provided by the nation's legislation. In this paper, the SME definition as proposed by the Brazilian Service to Support Micro and Small Enterprises [32] is followed. According to this regulation, SMEs can be classified as micro, small, or medium-sized, depending on the annual gross revenue (over US\$100,000.00 and equal to or lower than US $\$ 1,000,000.00)$. Table 1 describes the characteristics of the sixteen observed companies, with data for the year of 2017.

Data was obtained by interviews with the companies' managers. The requirement was that the participant should be knowledgeable about the reality of the company, with a minimum ten-year contract of employment. In the exploratory phase, a data collection instrument developed by the Ethos Institute, the "Self-Assessment and Planning-Ethos Indicators", was applied. This research instrument is composed of nine initial questions (which aim to introduce the questionnaire) and thirty-seven questions which, in turn, are divided into six major themes, being: values and transparency, internal audience, environment, supplier relationships, customer and/or/consumer relationships, and community relationships. Each topic can reach the maximum score of 10 points.

Subsequently, a comparative analysis of the performance by topic was performed, which consisted of a quantitative analysis obtained by adding the score in each theme. For the overall performance analysis, the overall sum achieved by the sum of the notes of the subjects in the self-assessment (maximum of 60 points) was considered. We considered sustainability practices that correspond to the reality of Brazil's SMEs. Table 2 describes the company's position regarding its reality in relation to corporate social responsibility. 
Table 1. Characteristics of the sixteen observed enterprises.

\begin{tabular}{|c|c|c|c|}
\hline Enterprises & Annual Gross Revenue & Number of Employees & Company Years \\
\hline E1 & US\$302,113.00 & 68 & 27 \\
\hline E2 & US\$928,543.00 & 109 & 22 \\
\hline E3 & US\$780,101.00 & 100 & 18 \\
\hline $\mathrm{E} 4$ & US\$401,021.00 & 74 & 20 \\
\hline E5 & US\$498,011.00 & 76 & 25 \\
\hline E6 & US\$562,629.00 & 88 & 10 \\
\hline E7 & US\$813,000.00 & 95 & 25 \\
\hline E8 & US $\$ 488,921.00$ & 77 & 29 \\
\hline E9 & US\$397,026.00 & 70 & 11 \\
\hline E10 & US\$765,917.00 & 90 & 10 \\
\hline E11 & US\$389,012.00 & 71 & 20 \\
\hline E12 & US\$503,842.00 & 85 & 14 \\
\hline E13 & US\$345,099.00 & 70 & 17 \\
\hline E14 & US\$651,946.00 & 86 & 16 \\
\hline E15 & US\$787,009.00 & 93 & 7 \\
\hline E16 & US\$381,134.00 & 69 & 15 \\
\hline
\end{tabular}

Source: Authors' own research.

Table 2. Company position regarding its reality in relation to corporate social responsibility.

\begin{tabular}{cl}
\hline \multicolumn{1}{c}{ Points } & \multicolumn{1}{c}{ Corporate Social Responsibility Position } \\
\hline From 0 to 15 points & $\begin{array}{l}\text { The company has great opportunities for improvement, as it does not yet have } \\
\text { a management focused on corporate social responsibility. The tool will aim to } \\
\text { plan a more structured way to increase the quality and the extent of the actions } \\
\text { focused on corporate social responsibility. }\end{array}$ \\
\hline From 16 to 35 points & $\begin{array}{l}\text { The company already carried out corporate social responsibility actions. } \\
\text { Analyze in detail the tool used, checking the topics with the highest score, and } \\
\text { what contributed to this result. }\end{array}$ \\
\hline From 36 to 50 points & $\begin{array}{l}\text { The company has already assimilated the concepts of corporate social } \\
\text { responsibility and has clarity of the commitments necessary for a socially } \\
\text { responsible performance. These commitments should bring positive aspects to } \\
\text { the business, through a closer and productive relationship with the parties } \\
\text { involved (government and society, community, employees, customers, } \\
\text { suppliers). At this stage, the company has matured some aspects of this action. }\end{array}$ \\
\hline From 51 to 60 points & $\begin{array}{l}\text { The company dominates emerging management concepts and uses corporate } \\
\text { social responsibility to achieve its goals. At this stage, it is clear the feasibility to } \\
\text { develop partnerships and intersectoral alliances, seeking to enhance the } \\
\text { company's performance, besides giving relevance to the systematization of } \\
\text { knowledge through collaborative actions. }\end{array}$ \\
\hline
\end{tabular}

Source: [33,34].

It is important to point out that the use of this research instrument was previously authorized by the Ethos Institute. For the analysis of the results, a matrix was presented containing the scores obtained in all dimensions by these companies. Furthermore, the average and the standard deviation for each dimension was analyzed. The overall score of the Ethos instrument was presented by a radar type chart. At end, the results are analyzed in comparison with results found in other research.

\section{Findings and Results}

The descriptive analysis shows that sustainability practices has a significant level of implementation in the sample companies, in general terms, of $29.18 \%$ (from a possible total of $60 \%$ ). Table 3 shows the cumulative points in each dimension of the research instrument per observed company. It is possible to observe that the practice implemented in most companies is that of good 
relationships with customers and/or consumers, with 7.81\% (total possible from 10\%); in addition, the low interaction with suppliers in compliance with legal labor obligations stands out, with $3 \%$ of the companies, along with values and transparency (4.37\%). The number of companies that do not have a channel to meet the demands of the community, with $3.07 \%$ implementation, is low.

The adoption of a clear and transparent attitude in relation to the company's ethical objectives and commitments strengthens the social legitimacy of its activities, reflecting positively in all its relations. Thus, the results found for values and transparency show that $50 \%$ of companies are above the sample average. The success of the company also depends on stakeholder participation, so it is necessary to ensure that its expectations and needs are known and considered by the managers. Engaging partners in defining business strategies generates mutual commitment to established goals. It is more effective when communication channels are provided to enable structured dialogue. The stakeholders have individual objectives and distinct cultural profiles in relation to social responsibility. In this study, the number of companies implementing these practices is also very high; more than $70 \%$ of the companies analyzed meet clear ethical criteria, which allows them to convey a responsible and trustworthy company image.

Table 3. Cumulative points in each dimension of the research instrument.

\begin{tabular}{|c|c|c|c|c|c|c|c|}
\hline Enterprises & $\begin{array}{l}\text { Values and } \\
\text { Transparency }\end{array}$ & $\begin{array}{c}\text { Internal } \\
\text { Audience }\end{array}$ & Environment & $\begin{array}{l}\text { Suppliers } \\
\text { Relationship }\end{array}$ & $\begin{array}{c}\text { Customers } \\
\text { and/or } \\
\text { Consumers } \\
\text { Relationship }\end{array}$ & $\begin{array}{l}\text { Community } \\
\text { Relationship }\end{array}$ & $\begin{array}{l}\text { Cumulative } \\
\text { Points }\end{array}$ \\
\hline E1 & 0.00 & 5.18 & 2.22 & 0.67 & 10.0 & 0.83 & 18.90 \\
\hline E2 & 7.50 & 7.40 & 8.88 & 5.41 & 7.50 & 7.08 & 43.77 \\
\hline E3 & 8.33 & 6.66 & 5.55 & 4.06 & 10.00 & 1.66 & 36.26 \\
\hline $\mathrm{E} 4$ & 2.50 & 6.29 & 3.33 & 1.35 & 7.50 & 2.91 & 23.88 \\
\hline E5 & 10.0 & 2.96 & 2.22 & 4.06 & 5.00 & 1.24 & 25.48 \\
\hline E6 & 0.83 & 4.44 & 7.77 & 5.41 & 9.16 & 4.16 & 31.77 \\
\hline E7 & 5.83 & 7.77 & 7.77 & 6.09 & 10.0 & 3.75 & 41.21 \\
\hline E8 & 1.66 & 2.96 & 4.44 & 4.06 & 7.50 & 3.33 & 23.95 \\
\hline E9 & 2.49 & 5.18 & 3.33 & 4.06 & 6.66 & 1.25 & 22.97 \\
\hline E10 & 5.83 & 5.18 & 8.88 & 3.38 & 8.33 & 3.33 & 34.93 \\
\hline E11 & 3.33 & 3.33 & 6.66 & 0.67 & 6.66 & 2.08 & 22.73 \\
\hline E12 & 6.66 & 5.92 & 6.66 & 0.67 & 10.0 & 1.25 & 31.16 \\
\hline E13 & 6.66 & 5.92 & 3.33 & 0.67 & 0.83 & 1.25 & 18.66 \\
\hline E14 & 1.66 & 6.66 & 6.66 & 2.03 & 10.0 & 5.83 & 32.84 \\
\hline E15 & 5.83 & 5.44 & 7.77 & 5.41 & 8.33 & 6.25 & 39.03 \\
\hline E16 & 0.83 & 3.70 & 4.44 & 0.00 & 7.50 & 2.91 & 19.38 \\
\hline Average & 4.37 & 5.31 & 5.62 & 3.00 & 7.81 & 3.07 & 29.18 \\
\hline $\begin{array}{l}\text { Standard } \\
\text { Deviation }\end{array}$ & 3.07 & 1.51 & 2.31 & 2.10 & 2.39 & 1.94 & 8.26 \\
\hline
\end{tabular}

Source: Authors' own research.

The shareholders aim to maximize profits; the State values compliance with legal obligations; the community perceives social responsibility as assistance; employees are anxious for the company to attract and retain employees, and therefore, the company sees social responsibility as a human resources policy, and an opportunity for new business. In short, everyone's goal is for the company to value sustainable development while preserving the environment $[7,28]$. The amount of companies implementing internal audience practices reached an average score of $5.31 \%$.

When visiting companies to explain the research and the delivery of self-assessment, the use of old personal protective equipment and collective protection equipment with dubious functionality was observed. As for hiring people with disabilities, a question inferred from the issues of self-assessment, it was noted that due to a lack of knowledge or lack of reasons to hire people with disabilities, few companies reported having employees with disabilities. The suggestion to achieve improvements in business management based on the concepts of corporate social responsibility is to review the internal policies of companies - or, if they do not formally exist, be formalized containing what the company can offer its employees. In addition, companies could offer incentives for sports leisure and health care. 
SMEs in the environmental field have developed good sustainability practices, with an implementation level of $5.62 \%$ (Table 3). It can be seen that $81.25 \%$ of companies are concerned with caring for and protecting the environment, for which $53.84 \%$ carry out specific initiatives to reduce energy consumption, $61.54 \%$ to reduce materials, and $46.15 \%$ to reduce water consumption. For other companies, before starting any practice, the management can seek information about the importance of environmental preservation and how some practices are beneficial to the environment, in addition to contributing in economic returns to the organization; for example, separate garbage waste collection, reduction of the expenses with paper (e.g., use of front and back sides), installation of taps with automatic closing, installation of discharges with reduced flow, and use of rainwater for industrial activities, among others.

In terms of suppliers, companies need to maintain good relations, comply with established contracts, and seek to encourage them to adopt socially responsible practices, ensuring that these contracts comply with environmental protection, safety, and nonuse of child labor. This dimension of the study shows the company's relationship with its suppliers, regarding verification of principles; social responsibility policy; and compliance with labor, social security, and tax laws. A low score on the principles and policy of social responsibility of suppliers is detected in the analysis of this issue, which denounces that if the supplier has quality products, more attractive prices, and a reasonable delivery time, it will be chosen, regardless of whether or not they use child labor, have discriminatory attitudes, withhold taxes, or comply with labor laws. Only four companies scored significantly, being E7 with $6.09 \%$; and E2, E6, and E15 with 5.41\% implementation.

Regarding customers/consumers, the companies were asked about communication with their final customers, providing instructions of their product and communication channels for suggestions, doubts, and complaints. Also part of this topic was the investigation about misleading content or that which induces customers/consumers to misuse the product provided, and the use of substances harmful to health. It is observed that practically all companies reached a satisfactory level (above 50\%) of implementation in this theme.

Some issues were designed to reveal the involvement level with the community around the company area, the use of the workforce residing in the neighborhood, the use of nearby suppliers, and the encouragement and dissemination of the importance of volunteer work and employee involvement in this type of action, among others. In total, $81.25 \%$ of the companies evaluated (E1, E3, E4, E5, E6, E7, E8, E9, E10, E11, E12, E13, and E16) did not reach half of the score possible, which means that these 13 companies are with a high level of disregard for the community.

The main factor leading to the low level of scoring in this theme is the fact that these companies are located in industrial parks and there are no residences close to or around the companies. The suggestion is to encourage employees to get involved in activities in their communities (sports, volunteer work with children or the elderly, and others) and disseminate these initiatives through websites, newspapers, internal communications, and/or organizational sustainability reports. As for the government and society, the administrators answered on the company's involvement with trade associations and regional forums, as well as the promotion of political debates and the stimulation of conscious voting.

The company's involvement with community spaces-plazas, schools, health posts, green areas, and others-were also verified by this theme. Companies seek financial support from government institutions. Where this support is not feasible, companies are not engaged in political action or mobilization in pursuit of improved conditions for business and the community.

In this research, an exploratory-descriptive study was carried out, which allowed us to go into detail on sustainability practices that SMEs in Brazil include in their management, allowing us to fulfil the objective of this research. It is observed that managers have a positive and favorable attitude towards CSR, but not enough for the expansion of practices in organizations. The practices considered have a low-medium implementation level of 4.86 points (total possible from 10 points) in economic sustainability, social sustainability, and environmental sustainability in the companies considered in the sample. Although this result is representative, the scope for improvement is still 
wide. The individual analysis of each of the items allows one to observe the weaknesses, and therefore, it is relevant information for companies as well as for the authorities involved in promoting the concept of sustainable enterprises. Based on the analysis of the average scores obtained for each of the items, the main strengths and weaknesses were observed. The four main strengths are related to the social image of the company and to human rights; the analyzed companies show concern that their supplier companies should also perform responsibly to convey the image of a responsible and reliable company.

Figure 1 shows the individual results of each company. Based on this, it is possible to notice that the size of the company (at the invoicing level) has a significant effect on the performance of small and medium-sized manufacturing enterprises; the age of the company has no relation with the practices of sustainability. The companies with the best performance were E2, E7, E15, and E3, respectively. All four companies, in addition to obtaining the best scores, also have the highest annual revenues, which can reinforce the idea of having greater power for investments in sustainable practices. It is worth mentioning that company E15, with its short time of existence (only seven years), already stands out in the sustainability aspect. It also reinforces the finding in the study of [22], describing that in Spain, the newer companies showed greater willingness to go beyond environmental legislation.

E1

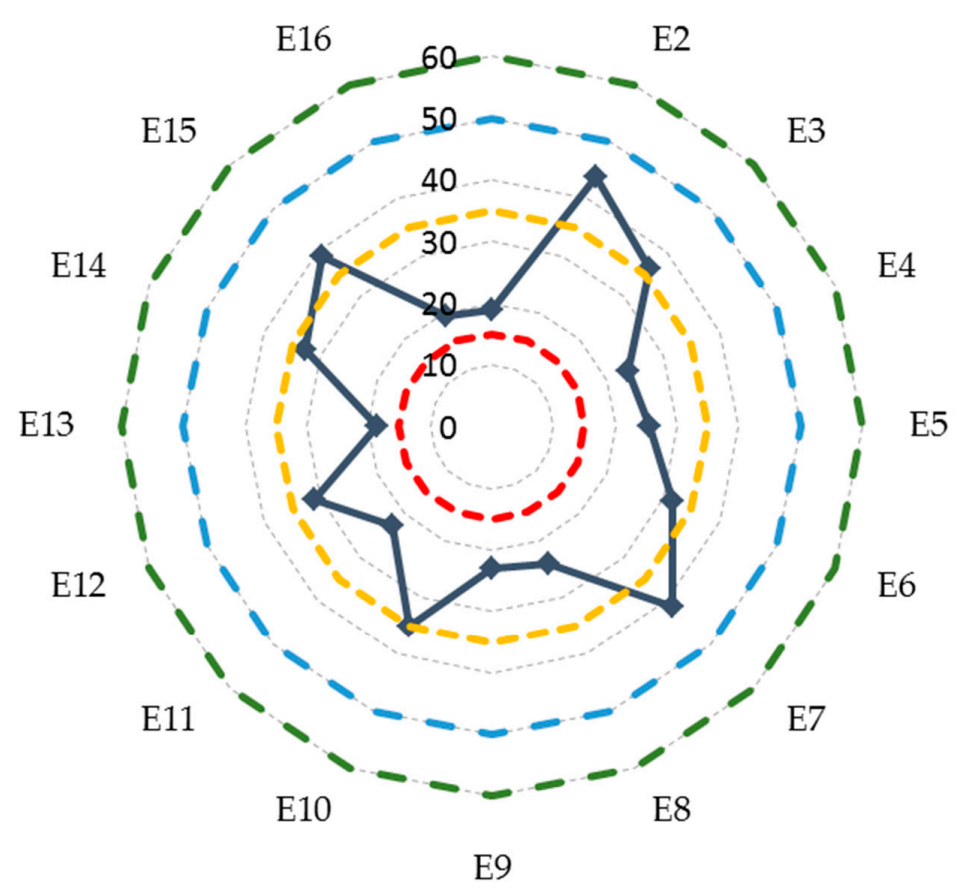

$\longrightarrow$ Cumulative Points --0 to $15---16$ to $35--36$ to $50--51$ to 60

Figure 1. Overall companies' scoring. Source: Authors' own research.

No companies scored between 51 and 60 points, which would indicate agreement with regard to emerging issues of management and the use of corporate social responsibility to achieve its objectives. Four companies surveyed scored between 36 and 50 points (E2 $=43.77 \%$; E3 $=36.26 \%$; E7 $=41.21 \%$; $\mathrm{E} 15=39.03 \%$ ), which indicates that companies have already assimilated the concepts of CSR and that they are committed to the requirements for a socially responsible performance. Through these commitments, positive aspects are expected for the business through a closer and more productive relationship with the involved parties (the government and society, community, internal public, customers, and suppliers).

The other companies scored between 12 and 35 points $(\mathrm{E} 1=18.9 \%$; E4 $=23.88 \%$; E5 $=25.48 \%$; $\mathrm{E} 6=31.77 \% ; \mathrm{E} 8=23.95 \% ; \mathrm{E} 9=22.97 \% ; \mathrm{E} 10=34.93 \% ; \mathrm{E} 11=22.73 \% ; \mathrm{E} 12=31.16 \% ; \mathrm{E} 13=18.66 \%$; 
$\mathrm{E} 14=32.84 \%$; E16 $=19.38 \%$ ), indicating that these companies already carry out actions focused on corporate social responsibility. None of the companies involved in the survey were in the score range from 0 to 15 points. Overall, the indexes show that there is a lot to be worked on when it comes to corporate social responsibility and that there are many opportunities to incorporate sustainability practices into Brazilian organizations.

In a survey conducted in Germany, corporate social responsibility (CSR) was studied as a dependent variable that is affected by the company's performance. In this research, it was verified that a company with strong monetary reserves is more involved in corporate social responsibility [35]. Another study carried out in Mexico found that CSR is a process of value creation [36]. Similarly, an empirical study [37] was carried out to find results of the implementation of CSR in the form of financial returns and presented a conclusive observation that the profitability of the companies is greater when they are oriented by CSR, indicating that the CSR and the company performance had a significant relationship.

In another study [38], the importance of the CSR with respect to the value aggregation was presented without taking into consideration what is sold by these companies. People are looking hard at how business is done, and companies that do it better win the race ahead of those for whom "corporate donations" are the only corporate responsibility index. The participation of companies in the Dow Jones Sustainability Index (DJSI) guarantees a status that gives it new business opportunities (mergers and partnerships), in addition to the expansion of the market, but this approach is restricted to large enterprises [12,39].

On the other hand, a study from Spain points out that sustainability reports are well established in large companies, but need to be introduced more extensively in small and medium-sized enterprises. The findings of this study indicate that CSR has a positive and significant influence on the distribution of value in favor of the State, a negative influence for the employees, and no influence on for the stakeholders [40]. In another study, this one conducted in Korea, CSR-related research has also been focused on large companies. There is a need for studies in SMEs that are comparable to research on large companies and that can compare corporate social performance with corporate financial performance [27]. Other results indicate that ethical practices have a positive impact on corporate governance, and in turn, corporate governance has a positive impact on CSR. The results also reveal a mediating effect of corporate governance on the relationship between ethics and CSR [41].

Aligned with this research, a study conducted in Korea with 38 companies investigated how employees' perceptions of the internal (endorsed by the company and aligned with their mission and values) and external (driven by practical or instrumental benefits) legitimacy of social responsibility activities of their company influenced their work practices. Internal legitimacy is considered to be more authentic than external legitimacy and has a more positive influence on organizational identification and employee affection. External legitimacy reduced the employee's perception of the authenticity of CSR, while internal legitimacy increased it. It has also been found that the authenticity of perceived CSR is an important mediator in the relationship between employees' perceptions of legitimacy and their work orientations [42]. Similarly, [43] applied a questionnaire among managers of small and medium-sized companies in Spain, totaling 481 companies, performing a more in-depth analysis of the returns generated to the main stakeholders of the business in which sustainable practices were implemented. The results highlighted a significant and positive effect that the CSR has on competitive performance.

In addition, both positive mediation effects were supported, company size was verified as a relevant control variable, and it was concluded that managers interested in a strategic social responsibility approach should be aware that investing in employee- and customer-related activities leads to greater organizational competitiveness. 


\section{Final Remarks}

This study is limited in its scope in the choice of the companies in the research SMEs, as well as its ability to evaluate the information coming from an evaluation instrument answered by the organization itself. Emphasis is placed on the importance of corporate involvement with corporate social responsibility for the world that presents itself as being globalized, competitive, and rapidly changing, in which companies are forced to seek new management alternatives to adapt to this reality. In this bias, the concept of corporate social responsibility has been consolidating in a multidimensional and systemic way across all levels and operations of the business, including also the relationship with the company's interlocutors.

By evaluating the practices of sustainability by SMEs, the need for several improvements with regard to corporate social responsibility was observed. They have all shown that they already know the subject and its importance, which is a good start. Nevertheless, future studies can rely on a multivariate statistical analysis, so as to form clusters of companies to try to identify common characteristics. Also, to further enrich this study, an evaluation of the influence of unions in corporate relations, which is a direct measure of CSR, could be addressed by interviewing key union leaders with specific questionnaires.

This study is an opportunity to discuss improvements in the understanding of the importance of the proposed theme. A starting point for future research, such as following up on the implementation of individual action plans with companies and future application of this same self-assessment to validate and revise all the actions implemented for improvement, as well as the maturity and evolution of the companies, are contributions of this paper. In addition, the creation of a project between companies and educational institutions for the development of a laboratory of corporate social responsibility is suggested, with the objective of uniting theory and practice, providing companies with the exchange of information and strengthening the implementation of these concepts. Finally, it is worth pointing out that the data used here was obtained through managers of the company, which might cause the risk of receiving skewed responses by one of the persons involved in the company. As a suggestion for continuation of the study, the authors recommend applying Harman's test. Also, it would be interesting to apply the study taking into account the response of the company's human resources, which would bring different points of view.

Author Contributions: All authors contributed equally to the article, collecting and analyzing the data; F.C.S. was responsible for the writing and initial conception of the article, R.R.Z. documented the literature and conceptual interpretation of the data, and A.L.K. carried out the critical review of the article and approval of the version to be published. R.S.J. and K.B.X.d.N. were responsible for field research, case study application, and final translation; all authors revised the paper.

Funding: This research did not receive external funding.

Conflicts of Interest: The authors declare no conflict of interest.

\section{References}

1. Cazeri, G.T.; Anholon, R.; da Silva, D.; Ordoñez, R.E.C.; Quelhas, O.L.G.; Leal Filho, W.; de Santa-Eulalia, L.A. An assessment of the integration between corporate social responsibility practices and management systems in Brazil aiming at sustainability in enterprises. J. Clean. Prod. 2018, 182, 746-754. [CrossRef]

2. Faller, C.M.; Zu Knyphausen, A.D. Does equity ownership matter for corporate social responsibility? A literature review of theories and recent empirical findings. J. Bus. Eth. 2018, 150, 15-40. [CrossRef]

3. Bansal, P. Envolving sustainably: A longitudinal study of corporate sustainable development. Strateg. Manag. J. 2005, 26, 197-218. [CrossRef]

4. Gladwin, T.N.; Kennelly, J.J.; Krause, T.S. Shifting paradigms for sustainable development: Implications for management theory and research. Acad. Manag. Rev. 1995, 20, 874-907. [CrossRef]

5. Sachs, I. Transition Strategies for the 21st Century: Development and Environment; Studio Nobel and Foundation for Administrative Development: São Paulo, Brazil, 1993. 
6. Anser, M.; Zhang, Z.; Kanwal, L. Moderating effect of innovation on corporate social responsibility and firm performance in realm of sustainable development. Wiley Corp. Soc. Responsib. Environ. Manag. 2018, 1-24. [CrossRef]

7. Ashley, P.A. Ethics and Social Responsibility in Business; Saraiva: São Paulo, Brazil, 2002; Volume 153.

8. Tinoco, J.E. Social Balance: An Approach to Transparency and Public Accountability of Organizations; Atlas: São Paulo, Brazil, 2006.

9. Anholon, R.; Quelhas, O.L.G.; Leal Filho, W.; de Souza Pinto, J.; Feher, A. Assessing corporate social Responsibility concepts used by a Brazilian manufacturer of airplanes: A case study at Embraer. J. Clean. Prod. 2016, 135, 740-749. [CrossRef]

10. Zylbersztajn, D.; Lins, C. Sustainability and Value Generation; Editora Campus: Rio de Janeiro, Brasil, 2010.

11. Milne, M.J.; Gray, R.W. Whither ecology? The triple bottom line, the global reporting initiative, and corporate sustainability reporting. J. Bus. Eth. 2013, 118, 13-29. [CrossRef]

12. Reverte, C.; Gómez-Melero, E.; Cegarra-Navarro, J.G. The influence of corporate social responsibility practices on organizational performance: Evidence from eco-responsible Spanish firms. J. Clean. Prod. 2016, 112, 2870-2884. [CrossRef]

13. El Baz, J.; Laguir, I.; Marais, M.; Staglianò, R. Influence of national institutions on the corporate social responsibility practices of small- and medium-sized enterprises in the food-processing industry: Differences between France and Morocco. J. Bus. Eth. 2016, 134, 117-133. [CrossRef]

14. Lee, L.; Chen, L. Boosting employee retention through CSR: A configurationally analysis. Corp. Soc. Responsib. Environ. Manag. 2018, 20, 874-907. [CrossRef]

15. Vilke, R. Corporate social responsibility as innovation: Recent developments in Lithuania. Econ. Bus. 2014, 26, 119-125. [CrossRef]

16. Agyemang, O.S.; Ansong, A. Corporate social responsibility and firm performance of Ghanaian SMEs: Mediating role of access to capital and firm reputation. J. Glob. Responsib. 2017, 8, 47-62. [CrossRef]

17. Hahn, R. ISO 26000 and the standardization of strategic management processes for sustainability and corporate social responsibility. Bus. Strategy Environ. 2013, 22, 442-455. [CrossRef]

18. Madzik, P.; Budaj, P.; Chocholáková, A. Practical experiences with the application of corporate social responsibility principles in a higher education environment. Sustainability 2018, 10, 1736. [CrossRef]

19. Arruda, L.R.; De Jesus Lameira, V.; Quelhas, O.L.G.; Pereira, F.N. Sustainability in the Brazilian heavy construction industry: An analysis of organizational practices. Sustainability 2013, 5, 4312-4328. [CrossRef]

20. Batista, A.A.D.S.; Francisco, A.C.D. Organizational sustainability practices: A study of the firms listed by the corporate sustainability index. Sustainability 2018, 10, 226. [CrossRef]

21. Lalangui, P.S.; Garcia, J.A.; Rio-Rama, M.C. Sustainable practices in small and medium-sized enterprises in Ecuador. Sustainability 2018, 10, 2105. [CrossRef]

22. Aguado, E.; Holl, A. Differences of corporate environmental responsibility in small and medium enterprises: Spain and Norway. Sustainability 2018, 10, 1877. [CrossRef]

23. Fethallah, W.; Chraibi, L. SMI's and CSR: A new approach for measuring social responsibility performance. Index Res. Gate 2017, 22, 115-128.

24. Hosoda, M. Management control systems and corporate social responsibility: Perspectives from a Japanese small company. Int. J. Bus. Soc. 2018, 18, 68-80. [CrossRef]

25. Lun-Thomsen, P.; Lindgreen, A.; Vanhamme, J. Industrial clusters and corporate social responsibility in developing countries: What we know, what we do not know, and what we need to know. J. Bus. Eth. 2016, 133, 9-24. [CrossRef]

26. Pantani, D.; Peltzer, R.; Cremonte, M.; Robaina, K.; Babor, T.; Pinsky, I. The marketing potential of corporate social responsibility activities: The case of the alcohol industry in Latin America and the Caribbean. Addiction 2017, 112, 74-80. [CrossRef] [PubMed]

27. Choi, J.H.; Kim, S.; Yang, D.H. Small and medium enterprises and the relation between social performance and financial performance: Empirical evidence from Korea. Sustainability 2018, 10, 1816. [CrossRef]

28. Martinez-Conesa, I.; Soto-Acosta, P.; Palacios-Manzano, M. Corporate social responsibility and its effect on innovation and firm performance: An empirical research in SMEs. J. Clean. Prod. 2017, 142, 2374-2383. [CrossRef]

29. Chun, H.M.; Shin, S.Y. The impact of labor union influence on corporate social responsibility. Sustainability 2018, 10, 1922. [CrossRef] 
30. Dey, P.K.; Petridis, N.E.; Petridis, K.; Malesios, C.; Nixon, J.D.; Ghosh, S.K. Environmental management and corporate social responsibility practices of small and medium-sized enterprises. J. Clean. Prod. 2018, 195, 687-702. [CrossRef]

31. Voss, C.; Tsikriktsis, N.; Frohlich, M. Case research in operations management. Int. J. Op. Prod. Manag. 2002, 22, 195-219. [CrossRef]

32. Brazilian Service to Support Micro and Small Enterprises. Available online: http:/ / www.sebrae.com.br/sites/PortalSebrae/ estudos_pesquisas/quem-sao-os-pequenos-negociosdestaque5,7f4613074c0a3410VgnVCM1000003b74010aRCRD (accessed on 2 May 2018).

33. Ethos Institute of Companies and Social Responsibility. Ethos Indicators of Corporate Social Responsibility. 2018. Available online: https:/ /www3.ethos.org.br/conteudo/indicadores (accessed on 1 April 2018).

34. Ethos Institute of Companies and Social Responsibility. Self-Assessment Tool and Planning: Ethos-SEBRAE Indicators of Corporate Social Responsibility for Micro and Small Companies. 2018. Available online: https://www3.ethos.org.br/conteudo/indicadores-ethos-publicacoes (accessed on 1 April 2018).

35. Fischer, T.M.; Sawczyn, A.A. The relationship between corporate social performance and corporate financial performance and the role of innovation: Evidence from German listed firms. J. Manag. Control 2013, 24, 27-52. [CrossRef]

36. Husted, B.W.; Allen, D.B. Strategic corporate social responsibility and value creation. Manag. Int. Rev. 2009, 49, 781-793. [CrossRef]

37. Rodriguez, F.M. Social responsibility and financial performance: The role of good corporate governance. BRQ Bus. Res. Q. 2016, 19, 137-151. [CrossRef]

38. Levick, R. Corporate Social Responsibility for Profit. Available online: https://www.forbes.com/sites/ richardlevick/2012/01/11/corporate-social-responsibility-for-profit (accessed on 18 April 2018).

39. Moore, S.B.; Manring, S.L. Strategy development in small and medium sized enterprises for sustainability and increased value creation. J. Clean. Prod. 2009, 17, 276-282. [CrossRef]

40. Fernández-Guadaño, J.; Sarria-Pedroza, J.H. Impact of corporate social responsibility on value creation from a stakeholder perspective. Sustainability 2018, 10, 1352. [CrossRef]

41. Elgammal, W.; El-Kassar, A.N.; Canaan Messarra, L. Corporate ethics, governance and social responsibility in MENA countries. Manag. Decis. 2018, 56, 273-291. [CrossRef]

42. Lee, S.; Yoon, J. Does the authenticity of corporate social responsibility affect employee commitment? Soc. Behav. Personal. Int. J. 2018, 46, 617-632. [CrossRef]

43. Martínez-Marínez, D.; Herrera Madueno, J.; Larran Jorge, M.; Lechuga Sancho, M.P. The strategic nature of corporate social responsibility in SMEs: A multiple mediator analysis. Ind. Manag. Data Syst. 2017, 117, 2-31. [CrossRef]

(C) 2018 by the authors. Licensee MDPI, Basel, Switzerland. This article is an open access article distributed under the terms and conditions of the Creative Commons Attribution (CC BY) license (http://creativecommons.org/licenses/by/4.0/). 